\title{
The Impact of Political
}

Connections and the Effectiveness of

Board of Commissioner and Audit

\section{Committees on Audit Fees}

Intan Ariningrum $^{1}$ and Vera Diyanty ${ }^{2}$

\begin{abstract}
This research aims to investigate the impact of political connection and effectiveness of Board of Commissioner and Audit Committee on audit fees. This research uses samples of Non financial companies listed in Indonesia Stock Exchange for the period 2012-2015. The Result of this study are that political connection can positively influence audit fees because the existence of political connection within the firm can increase firm's inherent risk that assessed by the auditor and the effectiveness of board of commissioner and audit committee can positively influence audit fees because they want higher audit quality from the auditor.
\end{abstract}

JEL Classification: M42, G34.

Keywords: Audit Fees, Political Connections, Effectiveness of Board of Commissioner, Effectiveness of Audit Committee.

${ }^{1}$ Universitas Indonesia, Indonesia.

${ }^{2}$ Universitas Indonesia, Indonesia. 


\section{INTRODUCTION}

Agency relationship is a term that can not be separated with business environment nowdays. Agency relationship is reffered as contractual relationship between the principal as an owner of the company and the agent as a manager who are trusted by the owner to make a decision regarding the company business (Jensen \& Meckling, 1976). Agency relationship may cause an agency conflict between the principal and the agent because they have different interest toward a company. To reduce the agency conflict, the principal needs to perform monitoring procedures to observe their agents. The monitoring procedures carried by the principal raise the agency costs. One form of agency costs are costs that incurred to perform audit procedures by the third parties (Jensen \& Meckling, 1976).

Related to the audit procedure, before performing audit procedures, the auditor will assess the company's risks (Ghosh and Tang, 2015). The higher the audit risk assessed by the auditor, the higher the audit effort required to generate appropriate audit opinion (Bedard \& Johstone, 2004). Therefore, the risk of audit will determine how much the audit fees to be paid by the company measured by how much effort is required by the auditor to perform the audit procedure. One form of audit risk assessed by the auditor is inherent risk attached to the company. The definition of inherent risk itself is the risk that assessed by the auditor in a company before considering the effectiveness of company's internal controls (Tuanakotta, 2013).

On the other hand, companies with political connection are associated with the higher of inherent risks (Gul, 2006) because the existence of political connections within the company increases the incidence of fraudulent practices committed by the company. Supporting this statement, Faccio (2006) argues that firms with political connection are associated with the practice of expropriation against minority shareholders. It can occur because politically connected firms have a potential chance to provide political donations to legislative candidates so that later elected legislative members can create policies that are beneficial for their companies (Kroszner and Stratmann, 1998). However, oftenly political donations which are given by the companies are not through the approval of all shareholders, meanwhile the funds or the resources are possessed by the shareholders as a whole (Faccio, 2006). Therefore, the practice of expropriation against the minority shareholders is believed to occur in politically connected firms. Moreover, the existence of political connections is also linked to earnings management practices (Chaney et al, 2011). Because of the fraudulent practices within the politically connected firms such as practice of expropriation and the practices of earnings management, they are associated with a low level of transparency in their financial statements (Walker \& Reid, 2002). Lack of transparency also has implications for the poor quality of financial statements that eventually will result in high risk of material misstatement on their financial reporting (Kan, 2006). The higher the risk, the higher the efforts required by the auditor to give an appropriate audit opinion. As a consequence the auditor will charge higher audit fees (Gul, 2006).

In addition to the existence of political connections within the company, there is another factor that can also influence the audit fees which is the effectiveness of GCG (Good Corporate Governance). Speaking of good corporate governance, the corporate governance principles drafted by the OECD, have one principle about the responsibility of the board as the supreme leader of a company that has the oversight function. To carry out their oversight function, the Boards may establish committees under them, one of which is the Audit Committee.

Regarding the effectiveness of Board of Commissioners and the effectiveness of the Audit Committee, previous studies found that there are different directions about its effect on audit 
fees. Research which is conducted by Yatim et al (2006) found that the independence of the Board of Commissioners and the competence of the Audit Committee are positively associated with audit fees due to the existence of Independent Commissioners and the presence of the Audit Committees who have expertise in accounting and finance are considered being able to provide surveillance system which is more objective. Effective monitoring system will result a demand for better audit quality. It will later have implications for the larger audit fees (Hay et al, 2006). On the other hand, the study conducted by Li and Wang (2006) in China found the opposite result where the independence of the Board of Commissioners is negatively correlated to audit fees charged by the auditor. This is because the auditors believe that the BOC who is more independent have more effective supervision levels, causing a lower risk regarding the internal control of the company. With the lower of control risks, the audit procedures required as substantive testing can also be reduced and ultimately impact on the reduction of audit fees (Knechel \& Willekens, 2006).

Associated with audit fees, to maintain their independence and integrity, Public Accounting Firms need to be made a guide in terms of the determination of the audit fees in order to avoid alow audit fees determined by the auditors that can reduce their integrity since they might perform the procedure below the standard (Indonesian Audit Standard Setter/IAPI, 2015). In Indonesia itself, policy on the determination of the audit fees already contained in the decree of IAPI No: KEP.024 / Certified / VII / 2008 about Policy Determination of Audit Fees. However, as revealed by IAPI in its report in 2016 that the application of the regulation mechanism is not optimal until today where there are still many Certified Public Accountants who do not disclose how they determine the amount of audit fees to be received. Therefore, IAPI in 2016 plans to issue a new decree revision in order to further guide as a reference, the amount of audit fees charged to the client. Given these rules have not been effectively implemented in Indonesia until 2016, then the audit fees determination factor in Indonesia still be an interesting theme to be researched. So, the purpose of this study is to provide empirical evidence of the factors that are believed to affect the audit fees which are the existence of political relations on a firm and effective supervision by the Board of Commissioners as well as the effectiveness of the Audit Committee.

The Research Gap from previous study is the using of the effectiveness of Board of Commissioner and Audit Committee instead of good corporate governance index as a whole such as in Wahab et al (2011). This study will be focus on BOC and Audit Committee's effectiveness in doing their surveillance system as one element of corporate governance that believed as the most influential factor to determine audit fees. Considering that BOC and Audit Committee have an authority to communicate with the auditor and to determine the scope of the audit work.

\section{LITERATURE REVIEW AND HYPOTHESIS DEVELOPMENT}

\section{The Agency Theory}

One form of agency costs that need to be issued by the principal is the bonding cost (Jensen and Meckling, 1976). Bonding costs itself are the costs incurred to create a guarantee that all actions taken by the management are aligned with the interests of shareholders, such as the costs for audit procedures (Jensen and Meckling, 1976). De Angelo (1981) argued that the costs of conducting the audit process are the most effective agency costs. Besides, it also stated that the 
costs for auditing are the smallest costs to reduce the conflict between principal and agent as well as conflicts between shareholders (majority vs. minority shareholders).

\section{Audit Risks and Audit Fees}

Before performing the audit procedures, auditor needs to conduct an assessment of the risks that are owned by the company (Ghosh and Tang, 2015). The risk assessment is the analysis performed by the auditor about the relevant risks associated with the preparation of company's financial statements (Arens et al, 2012). Audit risk is the risk of giving improper audit opinion regarding firm's financial statement (Tuanakotta, 2013). One of the audit risks is the inherent risk attached to the company. Inherent risk is vulnerability of an assertion is either on the types of transactions, account balance, or disclosure of the material misstatements that may own or incorporated without taking into account related control of the company (Tuanakotta, 2013). One form of inherent risk is the risk associated with the practice of fraud committed by management (Tuanakotta, 2013).

Taking into account the audit risk, auditor will determine the audit fees charged to the firm reflected on how much effort is required to perform audit procedures. Simunic (1980) developed a model which states that the audit fee is a function of audits (audit effort) and the risk of the auditor on the client's business (risk premium) where the higher the risk of audit considerated by the auditor, the higher the fee audit will be charged to the client because the amount of effort required to perform audit procedures. However, it is necessary to note that the determination of audit fees is not only from the point of view of the auditor as a provider of auditing services, but there is also the client's role as a party to use the services of audit in determining the audit fees they are willing to pay (Hay et al, 2006). The statement was later described by two theories.

The first theory is the supply-side theory that gives the view that the determination of the audit fees is based on the auditor's decision as a provider of audit services required by the client. So that the auditor has a role determining the audit fees to be paid depends on the variables attached to the clients seen through the viewpoint of the auditor. Examples of variables that assessed by the auditor to its client are the inherent risks of the client, and the client business complexity (Hay et al, 2006). For instance, if the auditor sees that a company has too many audit risks or even too complex, they will ask for higher audit fees paid by the client since they think that they will do more through audit procedures toward this company (Hay et al, 2006).

On the other hand, demand side theory itself explains how the client plays a role in determining the amount of audit fees they're willing to pay. So the amount of audit fees is not only determined by the auditor solely as a provider of audit services, but is also determined by the client as the parties who use their services (Hay et al, 2006). For example, a company who has effective good corporate governance implementation usually ask for a better audit quality to the auditor, so eventhough from the perspective of the auditor this company is less risky compare to other companies, the audit fees determined by them will usually higher than others because they need to perform more audit procedures in order to fulfill their demand to have better audit quality. Moreover, the company is also willing to pay higher audit fees in exchange for better audit quality. So, instead of less audit fees determined by the auditor because of the lower risks assessed by the auditor, the firms who implement good corporate governance might pay for higher audit fees because of the existence of demand side effect for a better audit quality (Hay et al, 2006). 


\section{Corporate Governance Theory and Political Theory}

Corporate governance is the relationship between the organs of companies consisting of management, the Board of Directors, Board of Commissioners, shareholders, and other stakeholders, to achieve the objectives of the company and is expected to provide value added for shareholders by taking into account other stakeholders (NCG 2006; IICG, 2009). To realize good corporate governance, each organ of the company has a different role, but they are interacting with each other. BOC as one of the organs of the company has the function to monitor the performance of the Board of Directors as specified in the UU PT No.40/ 2007. To achieve good corporate governance, the Board of Commissioners needs to ensure that oversight mechanisms do have run effectively. It is kind of adherence to the principles of the OECD number sixth which mentioned that good corporate governance should ensure the availability of effective supervisory mechanisms on the management by the Board of Commissioners. Therefore, the internal control performed by the Board of Commissioners is an essential element in achieving good corporate governance.

BOC have very important role in achieving good corporate governance as they have a responsibility to ensure that the management has implemented adequate internal control procedures and prepared financial reports reliably (Arens et al, 2012). Therefore, the presence of the Board of Commissioners who perform their oversight function effectively can improve the quality of the company's financial statements (Muller, 2014).

Related to perform surveillance functions according to UU PT No.40/2007, the Board of Commissioners may establish committees under them, including the Audit Committee, Nomination Committee and Remuneration Committee. According to the Keputusan Ketua Bapepam No: Kep-29 / PM / 2004 dated 24 September 2004 in conjunction with POJK 55/ POJK.04/2015 each public company listed in Indonesia Stock Exchange must have an Audit Committee. This means that every public company since 2004 is required to have an Audit Committee in order to assist the Board of Commissioners regarding their oversight function. The role of the Audit Committee is very important in helping the oversight function performed by the Board of Commissioners, mainly concerned with the supervision of the information on the financial statements issued by the management as one of the duties of the Audit Committee based on Keputusan Ketua Badan Pengawas Pasar Modal Nomor: Kep-29/PM/2004 dated 24 September 2004 in conjuction with Peraturan OJK No.55/POJK.04/2015 which examines the financial information that will be issued by the company.

In the other hand political theory in corporate governance explains that the existence of political connections within the company can influence the corporate governance structure and policy direction to be taken by the company (Pound, 1993). The theory also said that the existence of political connections characterized by any government involvement in the company may affect the mechanism of corporate performance (Hawley and William, 1996). Research conducted by Fisman (2001) suggest that political connections can be used as a tool to gain access from the government during the transition period, in which the economic system tends to be unstable and are associated with the value of the company. In addition, research conducted by Goldman et al (2010) showed that firms with political connections get ease regulations as well as the ease in obtaining government projects. Based on these studies it can be concluded that the existence of political relations within the company is believed to affect corporate performance through regulatory clearances, as well as the ease of getting a government project.

However, the advantages gained by politically connected firms raise political costs. A study shows that the presence of political connections can lead to exploitation and manipulation 
of political donations were given to the government or parties to make policies that are beneficial for their company, in the case of public companies, funds provided by the management, are owned by shareholders (Ramsay, Stapledon and Vernon, 2001). In addition, the politically connected firms are also associated with rent seeking behavior (Fisman, 2001). Therefore, political connections within the company may eventually trigger the expropriation activities against the minority shareholders because the funds given to conduct rent seeking activities do not always go through the approval of all shareholders despite expended funds are funds held by the shareholders as a whole (Faccio, 2006).

\section{Hypothesis Development}

\section{Impacts of Political Connections on Audit Fees}

Goldman et al (2010) found that the presence of political connection within the company can impact the performance of the company through the leniency regulation / policy and the ease in obtaining government projects. However, the advantages gained by the politically connected firms require costs. That is because to get the advantages, companies need to do rent seeking activity that is activity to lobby the authorities to create favorable policies for their companies in which this activity require funds or resources owned by the company (Fisman, 2001; Johnson and Mitton, 2002), The resources provided in the form of donations to the government or partyrelated work to make favorable policies for their companies pose a risk related to the exploitation and manipulation of the resources of the company because the donations itself do not always go through the approval of all shareholders, including minority shareholders (Ramsay, Stapledon and Vernon, 2001). Therefore, the existence of political connections within companies is often associated with practice of expropriation against minority shareholders and practices of earnings manipulation (Chaney, 2011).

This causes managers in politically connected firms have no incentive to do transparency. This is consistent with research conducted by Walker and Reid (2002) in Gul (2006) who found that the existence of political connections trigger lack of transparency in their financial statements which in turn resulting in a lower quality of financial reporting. In line with this, Chaney et al (2011) also gave the evidence that political connections can be associated with a lower quality of financial reporting due to a lack of transparency.

With the low quality of financial statements resulted by politically connected firms, it is believed that these firms have a higher inherent risk because there is a greater likelihood that a material misstatement occurred in the financial statements (2006). By the increase of auditor's assessment about the risk within the company including the inherent risk, the higher the audit effort required by the auditor to audit the company. Furthermore, a greater effort caused the auditor felt that they need to charge a larger amount of audit fees to the company (Gul, 2006). Therefore the politically connected firms are believed to pay audit fees greater than non-politically connected firms (Wahab, 2011).

Based on the above explanation, this study will test the hypothesis of a positive relationship between the existence of political relations in the company and the audit fees paid by the company.

\section{H1: The existence of political connections can positively affect audit fees.}




\section{The Impact of Effectiveness of Commissioners and the Audit Committee on Audit Fees}

Based on the structure of corporate governance in Indonesia, the Board is the highest organ of the company which has a supervisory function. To help carry out its oversight function, the Board of Commissioners may establish Committees below, namely the Audit Committee. Therefore, the effectiveness of supervision is in addition affected by the effectiveness of the company's Board also influenced by the effectiveness of the Audit Committee in helping to supervise. In relations with the audit fee, there are two arguments that describe the influence the effectiveness of supervision by the Board of Commissioners and the effectiveness of the Audit Committee of the audit fees.

The first argument is referred to as supply side theory as seen through the perspective of auditors, where the higher the effective functioning of the supervisory Board of Commissioners and the effectiveness of the Audit Committee will be implicated in increasing the quality of corporate governance. That way, the auditor believes there is a lower inherent risk within the company and will eventually lead the auditor to reduce audit fees charged to the firm (Wahab et al, 2011). Several research support this theory, Fama et al (1983) in Yatim et al (2006) found that the independence of the board as one of the characteristics of effective functioning of the supervisory board, provide mechanisms for oversight and effective control to reduce opportunistic behavior committed by managers and the practice of expropriation of the company's resources. As a result the auditor will reduce the substantive test that are needed and reduce audit fees to be charged (Knechel \& Willekens, 2006). In addition, research conducted by Ittonen et al (2010) found that the composition of the audit committee which is more qualified is negatively related to audit fees charged. In that study Ittonen et al (2010) found that the composition of the audit committee that is qualified is believed to increase the level of oversight and internal control, thereby reducing the inherent risk which is owned by the company. Inherent risk that these smaller may ultimately reduce audit fees due to reduced substantive testing procedures that need to be done by the auditor (Knechel and Willekens, 2006). So overall, these studies found that the effectiveness of supervision by the Board of Commissioners and is assisted by the Audit Committee, is negatively related to the audit fees.

On the other hand, demand side theory described by Hay et al (2006) tried to give arguments that the amount of audit fees to be paid by the companies is also determined by the company as a user. Hay et al (2006) states that there is demand side effect, resulting in a positive relationship between the implementation of good corporate governance, particularly in terms of supervision carried out by the Board of Commissioners and the audit fees. This is because the existence of an effective board can encourage companies / clients to obtain better audit quality will implicate for the high audit fees need to be paid (Hay et al, 2006). Therefore, according to Hay (2006) the existence of this theory then becomes an argument to explain why in previous studies as was done by Carcello et al (2002) as well as research conducted by Abbot \& Parker (2000) found that having a board that is effective will have a positive relationship with the audit fees.

Carcello (2002) found that the independence of the Board of Commissioners and the frequency of board meetings as a benchmark for effective oversight function are positively associated with audit fees. Another study conducted by Abbott \& Parker (2000) found that there is a positive relationship between the existences of an independent board with the audit fees. The argument behind this statement is that the independent board will try their best to maintain their reputation and are willing to give a maximum effort in order to fulfill its function as a supervisor of the company. Therefore, they would be willing to pay a higher audit fees for greater audit 
quality to protect their reputation and to avoid legal obligations as well as to promote the interests of other shareholders (Carcello et al, 2002). In addition to the effectiveness of the oversight function by the board, Lee and Mande (2005) found that the effectiveness of the Audit Committee also has a positive influence and significant impact on the amount of audit fees paid by companies. Based on these studies, it can be said that the characteristic function of effective oversight by the Board of Commissioners and the effectiveness of the Audit Committee proved to have a positive influence on the audit fees. Overall speaking, the arguments of the above studies that support this theory in line with the signaling theory in terms of the determination of the audit fee as disclosed by Wu (2012). Signaling theory described by Wu (2012) stated that the company would try to provide a signal to outsiders that they have implemented corporate governance seen by the effectiveness of the oversight function performed by the Board of Commissioners and is assisted by the Audit Committee. It is because they will ask for higher quality of audit services and ask for more thorough audit procedures. This in turn will have implications on the high amount of audit fees to be charged by the auditor.

With these two conflicting arguments, from the viewpoint of the auditor - supply side theory and from the point of view of the client - the demand side theory (Hay et al, 2006) which explains the two different directions on the effect of the effectiveness of the supervisory functions of the Board of Commissioners and the effectiveness of the Audit Committee on audit fees, then this hypothesis is two tail. Therefore, it can be hypothesized:

\section{H2: The effectiveness of Board of Commissioners and Audit Committee affect audit fees.}

\section{RESEARCH METHOD}

\section{Research Model}

The research model used in explaining the hypotheses 1 and 2 in this study draws on research from Wahab et al (2011) with Malaysia as an object of research and Wu (2012) with China as research objects. The research model is as follows:

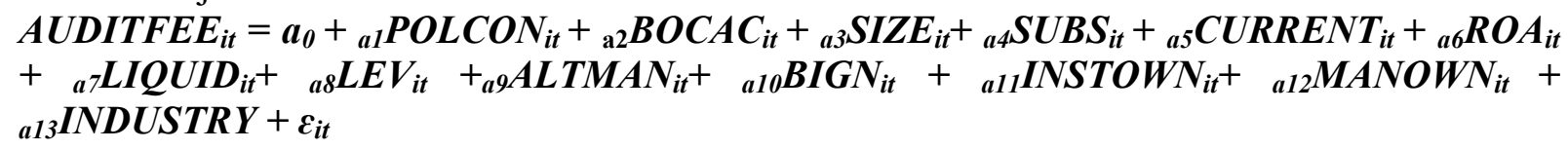

$\begin{array}{ll}\begin{array}{l}\text { Where applicable: } \\ \text { AUDITFEEit }\end{array} & =\begin{array}{l}\text { Amount of audit fees that company pay to the } \\ \text { auditors divided by } 1.000 .000 .000 .\end{array} \\ \text { POLCONit } & \begin{array}{l}\text { Political connections within the company. This } \\ \text { variable is a dummy variable, one for companies that } \\ \text { have political connections and } 0 \text { otherwise. }\end{array} \\ \text { BOCACit } & \quad \begin{array}{l}\text { Effectiveness of the Board of Commissioners and } \\ \text { Audit Committee (measured by checklist of } \\ \text { effectiveness of the Board of Commissioners and the }\end{array} \\ \text { SIZEit } & =\begin{array}{l}\text { Audit Committee developed by Hermawan (2009)). } \\ \text { Total assets of the company divided by }\end{array} \\ \text { SUBSit } & =\begin{array}{l}\text { Number of subsidiaries that are directly owned by } \\ \text { the company. }\end{array}\end{array}$




\begin{tabular}{|c|c|c|}
\hline CURRENTit & $=$ & Ratio of current assets to total assets. \\
\hline ROAit & $=$ & $\begin{array}{l}\text { Return on Assets (ratio of net profit before tax to } \\
\text { total assets). }\end{array}$ \\
\hline LIQUIDit & $=$ & Ratio of current assets to current liabilities. \\
\hline LEVit & $=$ & Ratio of total debt to total assets. \\
\hline ALTMANit & $=$ & $\begin{array}{l}\text { Altman } \mathrm{z} \text { score measuring the probability of } \\
\text { bankruptcy. }\end{array}$ \\
\hline BIGNit & $=$ & $\begin{array}{l}\text { Auditor who perform audit to the company, this } \\
\text { variable is a dummy variable, one for companies } \\
\text { using KAP Big } 4 \text {, and } 0 \text { otherwise. }\end{array}$ \\
\hline INSTOWNit & $=$ & Percentage shareholding of institutional investors. \\
\hline MANOWNit & $=$ & $\begin{array}{l}\text { Percentage shareholding of managerial ownership } \\
\text { (directors and commissioners) }\end{array}$ \\
\hline INDUSTRYit & $=$ & $\begin{array}{l}\text { Dummy variables to control the effects of the } \\
\text { industry. With a total of eight types of industries } \\
\text { based on the classification of IDX. }\end{array}$ \\
\hline
\end{tabular}

\section{Operasionalization Variables}

\section{Dependent Variable}

The dependent variable in this study is the cost of the audit or the audit fees. Data about the audit fees is taken from the annual reports of companies listed on Indonesia Stock Exchange from the year 2012-2015 which revealed the amount of the audit fees they have paid.

\section{Independent Variable}

\section{Political Connections}

In this study, a company classified to have political connections, if at least one of the company leaders (Board of Commissioners and Board of Directors), the majority shareholder (who has a stake above $10 \%$ ) or their close relatives were / are being served as a member of parliament, minister, or head of state, or close to the top-level politicians as well as if there is government's stake in the company. The criteria used to define political connections referred to a study Faccio (2006); Chaney et al, (2011); and Guedhami et al, (2010). This variable is a dummy variable that is, a value of 1 if the company has a political connection, and 0 otherwise.

There is an adjustment made on the criteria of political relations referenced in this study, which remove board members, directors or controlling shareholders of the incumbent or former of Indonesian Military Police of or the Indonesian Armed Forces in measurement. The reason to remove these criteria is the Army and Police, have no voice and political authority to choose and pick the top officials in the executive and the legislative, that's means have no political rights. This is in line with research conducted by Apriliani (2015). In addition, the close relationship to politicians in this research is limited to the core family relationships such as husband, wife, children, grandchildren, and siblings, in line with the research conducted by Faccio (2006). It is intended to limit the subjectivity in the assessment of political relations. 


\section{Effectiveness of Board of Commissioner and Audit Committee}

To assess the effectiveness of the Board of Commissioner, this study using the checklist effectiveness from research conducted by Hermawan (2009), which measures the effectiveness of BOC by using a checklist effectiveness consisting of 17 points criterias and are classified into four categories, namely the independence of the Board of Commissioners, the activity of the Board of Commissioners, the size of the Board of Commissioners, and the competence of the Board of Commissioners. While the effectiveness of the Audit Committee consists of 11 items and grouped into three categories. These categories are activities of the Audit Committee, the size of the Audit Committee, and the competence of the Audit Committee membership.

\section{Control Variables}

Control variables used in this study first is a measure of the company size. Company size is predicted to have a positive relationship to the audit fees because the larger the size of the company, the higher the level of complexity of the audit company (Simunic, 1980). In this study, the size of the company will be assessed using the total assets of the company (Gul, 2006). The second control variables used in this study is the number of wholly owned subsidiary companies. Simunic (1980) argued that the subsidiary is one form of decentralization and diversification owned by a company that could potentially fail the firm. It has implications for higher company's business risks. Therefore, in this study it is predicted that there is a positive relationship between the numbers of subsidiaries to the audit fee.

The next control variable is the ratio of current assets to total assets. Some components in the statement of financial position the company is considered to have higher risk levels than the other components (Simunic, 1980). In this case the current assets are considered to have a higher level of risk and audit procedures require more specialized and unspecialized (Wahab et al, 2011). Therefore, as a consequence the auditor find it necessary to charge a fee against larger audit firms with the ratio of current assets to total assets greater (Wahab et al, 2011).

Next is the control variable used to measure liquidity risk of companies. With the lower ability of the company's liquidity, it is predicted that the company is in a poor financial condition (Wahab et al, 2009). If the company is in poor financial condition, the company's going concern risk is higher and ultimately has implications for the larger audit procedures that need to be done by the auditor. The amount of high audit efforts will have implications on the high audit fees charged. Therefore, this is study predict that there is a negative relationship between the liquidity of companies with audit fees charged by the auditor. In addition to liquidity, there are other things that are also considered by the auditor to determine the risk inherent in the company, one of which is the company's degree of financial leverage. The higher a company's financial leverage, the higher the risk inherent in the company which is mainly related to the company's bankruptcy risk (Simunic and Stein, 1996). With the higher the risk assessed by the auditor, the higher audit fees to be charged by the auditor. Thus it is predictable that there is positive relationship between financial leverage of companies with audit fees charged by the auditor (Wahab et al, 2011).

To control the condition of financial difficulties experienced by the company, this study uses Altman bankruptcy prediction model as in research conducted by Gul (2006) and Wahab et al (2011). The smaller score of the company, the more likely the company is experiencing financial difficulties. The higher the financial difficulties experienced by the company, the higher the risks are assessed by the auditor to the company. Therefore, it is predicted that the negative 
correlation between the values obtained from the Altman bankruptcy prediction model with the audit fees.

This study is also using ROA to gauge profitability. Companies that have greater profitability are likely to choose an auditor with a better reputation in order to gain higher audit quality results and to provide a signal to outsiders that their company has had a good performance (Chaney \& Shivakumar, 2004). So it is predicted that ROA has positive correlation with the audit fees.

In addition, this study also uses variable size of public accounting firm that audited the company. Size of public accounting firms influence audit fees charged to clients for their monopoly power and the difference in the quality of audit provided by bigger publix accounting firms (Palmrose, 1986). Therefore, it is predicted that larger public accounting firms charge higher audit fees than other public accounting firms. Size public accounting firms in this study were divided into two categories by using dummy variables. Where 1 for companies audited by a large public accounting firm that belong to Big 4, while 0 otherwise.

This study also included institutional ownership and managerial ownership for control variables. In terms of the proportion of institutional ownership, this study predicts a positive influence on the amount of the audit fees charged. This is because as shareholders, institutional investors will ask for a higher quality of information, and as a result will ask for better quality audit to the auditor (Ali \& Lesage, 2013). On the other hand, this study predicts a negative correlation between the proportions of managerial ownership in the company to the amount of audit fees charged (Wahab et al, 2011). It is due to the managerial ownership in the company will align the interests of agents and principals in order to reduce agency conflicts that occur (Jensen \& Meckling, 1976). With the reduction of the agency conflict, it is expected to reduce audit risk assessed by the auditors and will result for lower audit fees charged (Fleming et al, 2005).

The last control variable used in this study is a type of industry. Some industries with certain characteristics have a higher degree of difficulty to carry out the audit process (Simunic, 1980) in Wahab (2011). In research Goodwin-Stewart \& Kent (2006) found that the mining industry proved to have higher audit fees than other industries. In addition to the research conducted by Wahab et al (2011) found that the industries that fall into the category of the construction industry, consumer goods, and technology have higher audit fees compared to other industries. Therefore, it can be said that this type of industry influence on the amount of audit fees paid to the auditor due to the different levels of difficulty and risks of each type of industry. Type of industries in this study refers to an industry classification made by IDX by dividing the company into eight types of industries.

\section{Population and Sample}

This research will use secondary data of companies listed in Indonesia Stock Exchange that disclose their audit fees in their financial statement. This study will observe companies in period of 2012 until 2015.

Table 1 below shows the results of sample selection: 
Table 1

\begin{tabular}{lcccc}
\multicolumn{5}{c}{ Research Sample } \\
\hline \multicolumn{1}{c}{ Explanations } & $\mathbf{2 0 1 2}$ & $\mathbf{2 0 1 3}$ & $\mathbf{2 0 1 4}$ & $\mathbf{2 0 1 5}$ \\
\hline Initial Sample & 447 & 484 & 498 & 507 \\
Financial Industry & $(71)$ & $(74)$ & $(79)$ & $(87)$ \\
Annual Report is Not Available & $(10)$ & $(6)$ & $(18)$ & $(27)$ \\
Audit Fee is Not Available & $(272)$ & $(263)$ & $(253)$ & $(232)$ \\
Total Companies & $\mathbf{9 4}$ & $\mathbf{1 4 1}$ & $\mathbf{1 4 8}$ & $\mathbf{1 6 1}$ \\
Total Observation (Unbalanced Panel) & \multicolumn{5}{c}{$\mathbf{5 4 4}$} \\
\hline
\end{tabular}

\section{Results and Analysis}

\section{Descriptive Statistics}

Based on descriptive statistics table below, it can be seen that the dependent variable in this research which is the audit fees have an average value of Rp 1.335 billion, -. This means that the average company in Indonesia in 2012 until 2015 to pay the amount of the audit fees of Rp 1.335 billion, - to the auditor. The range is quite high on this variable, seen from the difference between the maximum and minimum value, illustrate that the sample of firms in this study represents the nominal amount of the audit fees from small to large.

In addition, the descriptive statistics table below is also known that there are 182 companies who have political connections or approximately $33.46 \%$ of the total sample. These results also support the research conducted by Faccio (2006) that there are more than $28 \%$ of companies in Indonesia are politically connected.

A second independent variable in this study is the effectiveness of the Board of Commissioners and the Audit Committee as measured by checklist effectiveness of the Board of Commissioners and the Audit Committee which is used in research Hermawan (2009). The average value obtained from this variable is equal to 0.7847 . The resuls showed that on average, companies sampled in the study have had value on effectiveness of the Audit Committee of the Board of Commissioners that is good enough or were above fair value in a study conducted by Hemawan (2009). Fair value on research Hermawan (2009) in the amount of 0.6667 obtained from the amount of the effectiveness of the Board of Commissioners and the Audit Committee if the company gets a value of 2 for each questions.

Table 2

\section{Descriptive Statistics}

\begin{tabular}{lllll}
\hline Variable & Average & Std. Dev & Minimum & Maximum \\
\hline AUDITFEE (Rp Juta) & 1.335 & 1.828 & 44 & 10.512 \\
BOCAC & 0,7847 & 0,0772 & 0,4404 & 0,9524 \\
SIZE (Rp Milyar) & 8.827 & 12.832 & 47 & 61.024 \\
SUBS & 4,5237 & 5,5523 & 0 & 29,575 \\
MANOWN & 0,0242 & 0,0723 & 0,0000 & 0,3635 \\
CURRENT & 0,4612 & 0,2377 & 0,0039 & 0,9626 \\
LIQUID & 2,5233 & 5,3480 & 0,0116 & 67,4424 \\
ROA & 0,0439 & 0,1060 & $-1,0721$ & 0,4374 \\
LEV & 0,2329 & 0,1846 & 0,0000 & 0,8918 \\
INSTOWN & 0,0189 & 0,0343 & 0,0000 & 0,1414 \\
ALTMAN & 1,6513 & 2,5788 & $-8,1299$ & 11,7001 \\
\hline
\end{tabular}


Ariningrum \& Diyanty | Impact of Political Connections on Audit Fees

\begin{tabular}{llll}
\hline \multicolumn{4}{c}{ Variable Dummy } \\
\hline Variable & \%Score 1 & \%Score 0 & Total \% \\
POLCON & $(182) 33.46 \%$ & $(362) 66.54 \%$ & $(544) 100 \%$ \\
BIGN & $(256) 47.06 \%$ & $(288) 52.94 \%$ & $(544) 100 \%$ \\
INDAGRI & $(31) 5.7 \%$ & $(513) 94.3 \%$ & $(544) 100 \%$ \\
INDMIN & $(69) 12.68 \%$ & $(475) 87.32 \%$ & $(544) 100 \%$ \\
INDBASIC & $(96) 17.65 \%$ & $(448) 82.35 \%$ & $(544) 100 \%$ \\
INDCONS & $(42) 7.72 \%$ & $(502) 92.28 \%$ & $(544) 100 \%$ \\
INDMISC & $(39) 7.17 \%$ & $(505) 92.83 \%$ & $(544) 100 \%$ \\
INDPROP & $(83) 15.26 \%$ & $(461) 84.74 \%$ & $(544) 100 \%$ \\
INDINFRA & $(77) 14.15 \%$ & $(467) 85.85 \%$ & $(544) 100 \%$ \\
INDTRADE & $(106) 19.49 \%$ & $(438) 80.51 \%$ & $(544) 100 \%$ \\
\hline
\end{tabular}

AUDITFEE = total audit fees of a firm; POLCON = political connection that is owned by the company measured by using dummy variable; BOCAC = The effectiveness of the Board of Commissioners and Audit Committee score (Hermawan, 2009); SIZE = total assets of the company; SUBS = number of subsidiaries; MANOWN = percentage shareholdings of Directors and Commissioners; CURRENT = total current assets to total assets; LIQUID = total current assets to current liabilities; ROA = return on assets; $\mathbf{L E V}=$ total debt to total assets; BIGN = dummy public accounting firms Big 4 non-Big 4; ALTMAN = Altman z-score; INSTOWN = percentage of institutional ownership; INDAGRI = the agriculture industry; INDMIN = the mining industry; INDBASIC = base and chemical industry; INDCONS = consumer goods industry; INDMISC = other industries; INDPROP = construction property development, real estate, and building industry INDINFRA; = infrastructure, utilities and transportation industry; INDTRADE = trade, services and investments industry.

\section{Regression Results}

Result of tests performed on the model of this study showed that the result is consistent with the hypothesis that the first study stated that the existence of political connections are positively affect audit fees. Explanation of the result in this study is the existence of political relations within the company is believed to increase the inherent risk attached to the company (Gul, 2006). It is caused by the rent-seeking activities in companies with political connections (Faccio, 2006). Rent-seeking activities itself is an activity undertaken by politicians within the company by lobbying with the authorities and the government to influence policy-making process, which aims to benefit their company.

Activities undertaken by the company with the political connections cause costs in the form of political donations and private payments (bribes) in return (Ramsay et al, 2001; Hellman et al, 2000). Private payments (bribes) and political donations will raise the practice of expropriation of the minority shareholders. Expropriation practices against minority shareholders arise when political donations are given without the consent of all shareholders, including minority shareholders, while political donations are company's resources owned by the shareholders as a whole (faccio, 2006; Bliss et al, 2011). Therefore, to cover the practice of expropriation in the form of bribery, politically connected firm tend to have low transparency and also have the low quality of information in the financial statements (Bushman et al, 2004; Chaney et al 2011).

With the low level of transparency and the poor quality of information in financial reports generated, a company that has political connections is believed to have a greater inherent risk, especially in the information in the financial statements presented. The high risk that the auditor assessed then the more audit procedures required such as substantive testing and gathering audit 
evidence. As a result the auditor would increase the cost of the audit were higher in companies that have political connections (Gul, 2006).

Result of tests performed on the second hypothesis in this study also shows that the second hypothesis is proved which states that the effectiveness of the Audit Committee and the effectiveness of Board of Commissioners have positive effect on audit fees..

In practice in determining the audit fees paid to auditor, is not only can be seen from the viewpoint of the auditor as audit service providers, but there is also the client's role in determining the audit fees that they are willing to pay (Hay et al, 2006). The role of the client in determining the audit fees paid referred to as a demand side effect. In this study the demand side effect proved to make a positive influence between the effectiveness of the Board of Commissioners and the Audit Committee and audit fees.

This is because companies that have the Board of Commissioners and the Audit Committee who are more effective will encourage the company to get a better audit quality (Carcello et al, 2002; Lee \& Mande, 2005). It is intended to maintain their reputation and to protect themselves from legal liability that may occur in the future because of the low level of supervision performed (Carcello et al, 2002; Goodwin-Stewart \& Kent, 2006). In addition, the Audit Committee who is more effective will also increase their demand for quality of audit by increasing coverage or scope of the audit (audit coverage) should be made by the auditors (Lee \& Mande, 2005). With the demand for better audit quality and the demand for wider audit coverage, the company is willing to pay higher audit fees (Goodwin-Stewart \& Kent, 2006).

Therefore, the result of this study supports the argument of the demand side theory which states that the higher the level of effectiveness of surveillance conducted by the Board of Commissioners and the higher the effectiveness of the Audit Committee to assist the Board of Commissioners to supervise management, the higher the demand for better audit quality. The demand for high audit quality will in turn affect higher audit fees charged by the auditor (Carcello et al. 2002; Bliss et al., 2011).

Table 3

Regression Results

\begin{tabular}{llll}
\hline Variabel & Coefficient & Sig & Explanation \\
\hline POLCON & 0,3902235 & $0,001^{* * *}$ & Significant \\
BOCAC & 1,017764 & $0,080^{*}$ & Significant \\
SIZE & 0,0000466 & $0,000^{* * *}$ & Significant \\
SUBS & 0,081219 & $0,000^{* * *}$ & Significant \\
CURRENT & $-0,012414$ & 0,481 & Not Significant \\
ROA & 0,7720022 & $0,005^{* *}$ & Significant \\
LIQUID & $-0,001877$ & 0,387 & Not Significant \\
LEV & 0,1238569 & 0,342 & Not Significant \\
ALTMAN & 0,0346735 & $0,008^{* *}$ & Significant \\
BIGN & 0,6598435 & $0,000^{* * *}$ & Significant \\
INSTOWN & 0,5130759 & 0,394 & Not Significant \\
MANOWN & 0,2109963 & 0,422 & Not Significant \\
INDAGRI & 0,324361 & 0,442 & Not Significant \\
INDMIN & 0,4060905 & $0,086^{*}$ & Significant \\
INDPROP & $-0,138191$ & 0,311 & Not Significant \\
INDINFRA & 0,4973408 & $0,045^{* *}$ & Significant \\
INDTRADE & $-0,329800$ & 0,962 & Not Significant \\
\hline Nilai Prob $>\mathrm{F}=0,0000$ & & & \\
Nilai Adjusted $\mathrm{R}^{2}=0,5413$ & & & \\
N (Jumlah Observasi) $=544$ & & & \\
\hline
\end{tabular}




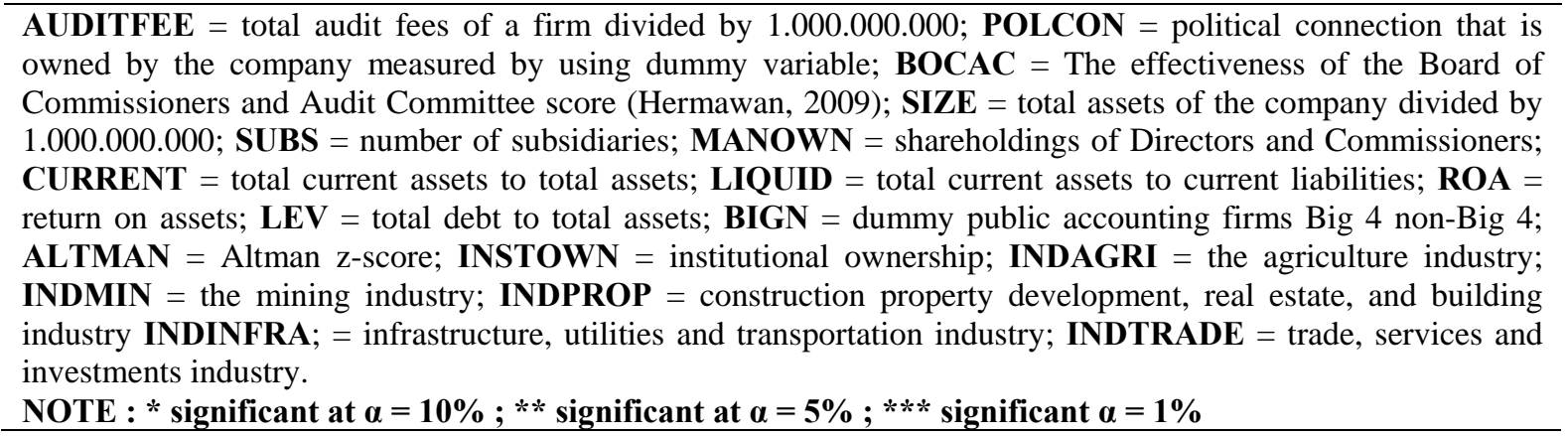

\section{CONCLUSION, LIMITATION AND FUTURE RESEARCH}

This study aimed to analyze the effect of the existence of political relations as well as the effectiveness of the Board of Commissioners and the effectiveness of the Audit Committee of the audit fee. Based on the results of the first hypothesis testing found that the existence of political relations positive effect on audit fees. The explanation of these results is that the existence of political relations within the company is believed to increase the inherent risk attached to the company for their activity of rent seeking behavior and practices towards minority shareholders ekpropriasi through political donations given to lobby with the authorities. Therefore, from the perspective of the auditors, the company is considered to have a higher risk than other companies that do not have political connections and consequently auditors will increase audit effort required and the implications for the high fee audit charged (Wahab et al, 2011).

In addition, the results of this study also found that there is a positive influence between the effectiveness of the Board of Commissioners and the Audit Committee of the audit fee. The results of this study support the argument of the demand side theory which states that the Board of Commissioners effective and effective Audit Committee will exert their best to conduct surveillance. Therefore, they will ask for better audit quality that has implications for the high audit fees to be charged (Gul, 2006).

There are several limitations in this study. First, this study is lack of audit fees data since the companies that are willing to disclose their audit fees data are still limited. Another limitation of this study is the subjectivity to assess political connections within a firm. This is because in Indonesia there is no trustable resource that can determine the relationship between someone and politicians so we can only rely on online mass media information. The last limitation is we did not use the effectiveness of BOC and Audit Committee as moderating variables between the relationship of political connections and audit fees. Although it is believed that the effectiveness of BOC and Audit Committee can make the relationship between the political connections and audit fees become weaken.

The suggestions in this study for further research is to find other sources regarding the amount of audit fees incurred by the company apart from its annual report that is expected to increase the number of research samples. It is also expected in future studies in order to obtain a more credible source related to one's relationship with politicians. Moreover, in the later study suggested that the variable effectiveness of the Board of Commissioners and the Audit Committee serve as a moderating variable. This is because the presence of the Board of Commissioners and the Audit Committee effective believed to weaken the influence of the political relations of the audit fee for their more effective monitoring mechanisms so as to reduce audit risk assessed by the auditors of the companies that are politically connected. 


\section{REFERENCES}

Abbott, L., Parker, S., Peters, G., \& Raghunandan, K. (2003). The Association between Audit Committee Characteristics and Audit Fees. Auditing: A Journal of Practice \& Theory, 17-32. https://doi.org/10.2308/aud.2003.22.2.17

Abdullah, H., \& Valentine, B. (2009). Fundamental and Ethics Theories of Corporate Governance. Middle Eastern Finance and Economics , 88-96.

Abdulmalik, S., \& Shittu, I. A. (2015). Political Connections of Boards and the Selection of Auditors in Nigeria. International Journal of Economics and Financial Issues , 104-110.

Apriliani, A. (2015). Pengaruh Kepemilikan Keluarga dan Hubungan Politik terhadap Manajemen Laba. Skripsi Fakultas Ekonomi Universitas Indonesia

Arens, A., Elder, R., Beasley, M., \& Jusuf, A. (2012). The Demand for Audit and Other Assurance Services. Jakarta: Salemba Empat.

Bedard, J., \& Johstone, K. (2004). Earning Management Risk, Corporate Gvernance Risk, and Auditors' planning and Pricing Decision. The Accounting Review , 277-304. https://doi.org/10.2308/accr.2004.79.2.277

Bliss, M., Gul, F., \& Majid, A. (2011). Do political connections affect the role of independent audit committees and CEO Duality? Some evidence from Malaysian audit pricing. Journal of Contemporary Accounting \& Economics , 82-98. https://doi.org/10.1016/j.jcae.2011.10.002

Bushman, R., \& Piotroski, J. (2004). What Determines Corporate Transparency. Journal of Accounting Research . https://doi.org/10.1111/j.1475-679X.2004.00136.x

Carcello, J., Hermanso, D., Neal, T., \& Riley, R. (2002). Board Characteristics and Audit Fees. Contemporary Accounting Research, 365.

https://doi.org/10.1506/CHWK-GMQ0-MLKE-K03V

Chaney, P., Faccio, M., \& Parsley, D. (2011). The Quality of Accounting Information in Politically Connected Firms. J. Account. Econ, 58-76. https://doi.org/10.1016/j.jacceco.2010.07.003

Chaney, P., Shivakumar, L., \& Jeter, D. (2004). Self-selection of auditors and audit pricing in private firms. The Accounting Review , 51-72. https://doi.org/10.2308/accr.2004.79.1.51

De Angelo, E. (1981). Auditor Size and Audit Quality. Journal of Accounting and Economics, 183-199. https://doi.org/10.1016/0165-4101(81)90002-1

Faccio, M. (2006). Politically Connected Firms. The American Economic Review2006 , 369386. https://doi.org/10.1257/000282806776157704

Fama, E., \& Jensen, M. (1983). Separation of Ownership and Control. Journal of Law and Economics , 301-325. https://doi.org/10.1086/467037

Firth, M., Fung, P., \& Rui, O. (2006). Corporate performance and CEO Compensation in China. Journal of Corporate Finance , 693-714. https://doi.org/10.1016/j.jcorpfin.2005.03.002

Fisman, R. (2001). Estimating the Value of Political Connections. The American Economic Review , 1095-1102. https://doi.org/10.1257/aer.91.4.1095

Fleming, G., Heaney, R., \& McCosker, R. (2005). Agency costs and ownership structure in Australia. Pacific-Basin Finance Journal , 29-52. https://doi.org/10.1016/i.pacfin.2004.04.001

Ghosh, A., \& Tang, C. Y. (2015). Assessing financial reporting quality of family firms: The auditors' perspective. Journal of Accounting and Eonomics , 95-116. https://doi.org/10.1016/i.jacceco.2015.03.002

Godard, A., \& Masters, C. (2000). Audit committees, Cadbury Code and audit fees: an empirical analysis of UK companies. Managerial Auditing Journal , 358-371. 
Ariningrum \& Diyanty | Impact of Political Connections on Audit Fees

https://doi.org/10.1108/02686900010344638

Goldman, E., Rocholl, J., \& So, J. (2009). Do Politically Connected Boards Affect Firm Value? The Review of Financial Studies . https://doi.org/10.1093/rfs/hhn088

Goodwin-Stewart, J., \& Kent, P. (2006). Relation between external audit fees, audit committee characteristics and internal audit. Accounting and Finance, 387-404. https://doi.org/10.1111/i.1467-629X.2006.00174.x

Guedhami, O., Pittman, J., \& Saffar, W. (2010). Auditor Choice in Privatized Firms: Empirical Evidence on the Role of State and Foreign Owners. Journal of Accounting and Economics , 179-234.

Gul, F. A. (2006). Auditors' Response to Political Connections and Cronyism in Malaysia. Journal of Accounting Research , 931-963. https://doi.org/10.1111/i.1475-679X.2006.00220.x

Hackenbrack, K., \& Knechel, W. (1997). Resource allocation decisions in audit engagement. Contemporary Accounting Research , 481-499. https://doi.org/10.1111/j.1911-3846.1997.tb00537.x

Hawley, J., \& Williams, A. (1996). Corporate Governance in the United States: The Rise Of Fiduciary Capitalism. Working Paper, Saint Mary's College of California, School of Economics and Business Administration .

Hay, D., Knechel, W., \& Ling, H. (2006). Audit Fees A Meta Analysis of the Effect of Supply and Demand Attributes. Contemporary Accounting Research , 141-191. https://doi.org/10.1506/4XR4-KT5V-E8CN-91GX

Hellman, J., Jones, G., \& Kaufmann, D. (2006). Seize the state, seize the day. State capture, corruption, and influence in transition. Journal of Comparative Economics , 411-439.

Hermawan, A. (2009). Pengaruh Efektivitas Dewan Komisaris dan Komite Audit, Kepemilikan oleh Keluarga dan Peran Monitoring Bank Terhadap Kandungan Informasi Laba. Disertasi S3 Program Ilmu Akuntansi UI .

Ittonen, K., Miettinen, J., \& Vahamaa, S. (2010). Does Female Representation on Audit Committees Affect Audit Fees? Quarterly Journal of Finance and Accounting, 113-139.

Jensen, M. C., \& Meckling, W. H. (1976). Theory of the firm: Managerial behavior,agency cost and ownership structure. Journal of Financial Economics , 3(4), 305-360. https://doi.org/10.1016/0304-405X(76)90026-X

Keputusan Ketua BAPEPAM Nomor: Kep-29/PM/2004 Mengenai Pembentukan dan Pedoman Pelaksana Kerja Komite Audit

Knechel, W., \& Willekens, M. (2006). The Role of Risk Management and Governance in Determining Audit Demand. Journal of Business Finance and Accounting , 1344-1367. https://doi.org/10.1111/.1468-5957.2006.01238.x

Kroszner, R. S., \& Stratmann, T. (1998). Interest Group Competition and the Organization of Congress: Theory and Evidence from Financial Services' Political Action Committeees. The American Economic Revies , 1163-1187.

Lee, H. Y., \& Mande, V. (2005). The Relationship of Audit Committee Characteristics with Endogenously Determined Audit and Non- Audit Fees. Quarterly Journal of Business and Economics , 93-112.

Li, B., \& Wang, P. (2006). Board characteristics and ratios of audit fee to asset. China Accounting Review , 105-118.

Palmrose, Z. (1986). Audit fees and auditor size: Further evidence. Journal of Accounting and Research , 97-110. https://doi.org/10.2307/2490806 
Peraturan Bapepam LK Nomor X.K.6 Tahun 2012 Tentang Penyampaian Laporan Tahunan Emiten atau Perusahaan Publik

Peraturan OJK No. 55/POJK.04/2015 Mengenai Pembentukan dan Pedoman Pelaksana Kerja Komite Audit

Pound, J. (1993). Proxy Contest And The Efficiency Of Shareholder Oversight. Journal of Financial Economics , 237-265.

Ramsay, I., Stapledon, G., \& Vernon, J. (2001). Political Donations By Australian Companies. Federal Law Review, 29 , 177-218. https://doi.org/10.2139/ssrn.286112

Simunic, D. (1980). The pricing of audit services: Theory and evidence. Journal of Accounting Research , 161-190. https://doi.org/10.2307/2490397

Surat Keputusan IAPI Nomor Kep 024/IAPI/VII/2008 Tentang Kebijakan Penentuan Fee Audit

Tuanakotta, T. (2013). Audit Berbasis ISA (International Standards on Auditing). Jakarta : Salemba Empat.

Undang-Undang Nomor 40 Tahun 2007 tentang Perseroan Terbatas

Wahab, E. A., Zain, M. M., \& James, K. (2011). Political Connections, Corporate Governance and Audit Fees. Managerial Auditing Journal , 393-418. https://doi.org/10.1108/02686901111129562

Walker, G., \& Reid, T. (2002). Upgrading Corporate Governance in East Asia. Journal of International Banking Law , 59-66.

Watts, R. L. (1977). Corporate Financial Statements, A Product of the Market and Political Process. Australian Journal of Management . https://doi.org/10.1177/031289627700200104

$\mathrm{Wu}, \mathrm{X}$. (2012). Corporate governance and audit fees: Evidence from companies listed on the Shanghai Stock Exchange. China Journal of Accounting Research , 321-342. https://doi.org/10.1016/j.cjar.2012.10.001

Yatim, P., Kent, P., \& Clarkson, P. (2006). Governance Structures, Ethnicity, and Audit Fees of Malaysian Listed Firms. Managerial Auditing Journal , 757-782.

https://doi.org/10.1108/02686900610680530 